\title{
PENGUJIAN EKSPERIMENTAL UNTUK MEMPELAJARI KARAKTERISTIK GETARAN PADA MODEL ROTOR GANDA KIT MENGGUNAKAN ANALISIS PETA SPEKTRUM DAN ORBIT
}

\author{
Noor Eddy \\ Jurusan Teknik Mesin Fakultas Teknologi Industri Universitas Trisakti \\ e-mail: nooreddy.mt@gmail.com
}

\begin{abstract}
In modern technology, vibration signal is to be utilized in predictive maintenance application, more often when Dynamic Signal Analyzer (DSA) is invented. Unballance in rotor cause significant deflection on rotated shaft and possible damage the machine. DSA is used in monitoring a condition of big rotation machines such as turbin, compressor, pump and generator. This research used double rotors shaft system which was supported with journal bearing as a modification from the real rotation machines. Two of vibration characteristic as a sign of abnormal condition in rotation machine are unballance and oil whirl phenomenon. Meanwhile, oil whirl is seen in many rotation machines that use journal bearing as support its shaft. For rotation machine with high speed, oil whirl phenomenon can cause resonance in the system, and then become the oil whip. Based on this condition that is very reasonable for making early detection, identification, and looking for the solution to prevent not wanted incident.
\end{abstract}

Keywords: vibration signal, unbalance, oil whirl, oil whip, power spectrum, and orbit.

\section{PENDAHULUAN}

Perawatan mesin merupakan aspek yang memegang peranan penting dalam kelangsungan proses produksi. Metode Perawatan Run to Breakdown biasa diterapkan pada perusahaan yang mengoperasikan permesinan dengan harga yang relatif murah dan memiliki beberapa mesin cadangan. Sedangkan untuk perusahaan yang menggunakan mesin-mesin kritis tanpa ada mesin cadangannya, metode pencegahan berbasis waktu dapat digunakan. Seiring dengan kemajuan teknologi permesinan, kedua jenis metode perawatan di atas mulai ditinggalkan karena dirasa kurang ekonomis. Hal ini disebabkan kedua metode perawatan ini tidak dapat menentukan penyebab kerusakan dan kapan terjadinya kerusakan secara akurat sehingga pengeluaran biaya perawatan mesin dalam jumlah yang besar berlangsung secara terus menerus. Alternatif penerapan metode perawatan prediktif diharapakan dapat menekan biaya perawatan pada perusahaan yang menggunakan mesin-mesin dengan harga mahal dan memegang peranan vital dalam proses produksi.

Mesin-mesin rotasi berukuran besar, seperti turbin, pompa, generator dan kompresor, biasanya menggunakan bantalan luncur untuk menumpu porosnya. Masalah yang mungkin timbul sebagai gejala kerusakan yang umum terjadi adalah adanya getaran karena ketidakseimbangan elemen rotasi (rotor) dan ketidakstabilan induksi fluida (oil whirl). Kedua masalah tersebut apabila didiamkan akan mengakibatkan kerusakan yang semakin besar. Sistem akan mengalami getaran yang semakin besar dan bukan tidak mungkin akan terjadi resonansi antara frekuensi pribadi sistem dengan frekuensi rangsangan yang disebabkan oleh bekerjanya sistem, seperti kecepatan kritis poros ataupun frekuensi oil whirl, yang dapat mengakibatkan kerusakan pada sistem. Berdasarkan pada kondisi tersebut maka dibuat suatu model uji berupa sistem poros rotor ganda yang ditopang oleh bantalan luncur pada kedua porosnya untuk mendeteksi adanya gejala unbalance dan fenomena oil whirl. Hasil pengujian selanjutnya dianalisis dengan harapan dapat dicari suatu solusi dari permasalahan yang ada.

Dengan analisis getaran waktu pebaikan dapat di prediksi dan dimonitor kejadian kerusakan komponen tersebut, dan proses perbaikannya lebih cepat karena dapat mempersiapkan komponenkomponen yang perlu diganti. Analisis spektrum getaran yang dilakukan menitikberatkan pada analisis orbit dan fasa untuk mendeteksi fenomena oil whirl dan terjadinya oil whip apabila beresonansi dengan putaran kritis.

Tujuan penelitian ini adalah melakukan pengujian dan analisis getaran rotor ganda. Pengujian menggunakan rotor kit dengan mengamati karakteristik bantalan luncur tumpuan kiri dan 
tumpuan kanan. Pembuatan peta spektrum dan orbit, menganalisis kapan terjadinya oil whirl dan oil whip, kemudian dilakukan metode penyeimbangan dinamik tiga massa coba $120^{\circ}$ model rotor kit untuk menganalisis perbandingan sebelum dan sesudah diseimbangkan.

Manfaat penelitian ini untuk perkembangan dunia teknik pada kegiatan eksperimental mesin-mesin rotasi. Perkembangan pada laboratorium getara pada laboratorium jurusan mesin pada khususnya.

\section{Metode Penyeimbangan Dinamik Tiga Massa Coba $120^{\circ}$}

Proses penyeimbangan suatu elemen mesin yang melakukan gerak rotasi, salah satunya dapat dilakukan dengan metode penyeimbangan tiga massa coba $120^{\circ}$. Dalam pengujian ini digunakan poros dengan dua rotor sehingga diperlukan dua buah ICP accelerometer untuk mencuplik getaran pada tiap bidang. Pada metode ini, ketiga massa coba mempunyai berat yang sama dan posisinya membentuk sudut $120^{\circ}$ satu dengan yang lain seperti terlihat pada Gambar 1 , di samping itu diasumsikan bahwa getaran pengganggu (noise) adalah kecil sehingga amplitudo getaran (x) proporsional terhadap massa yang ditambahkan.

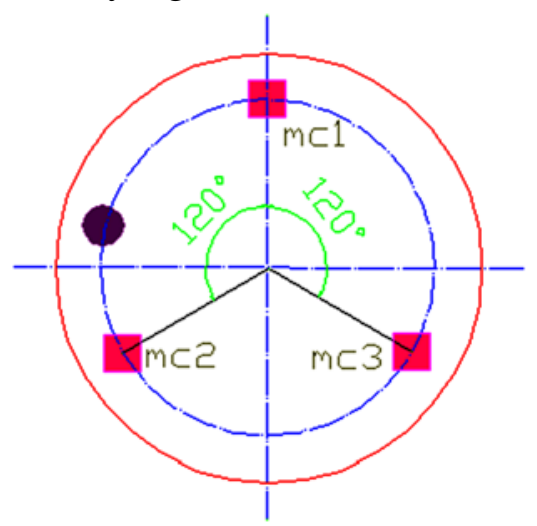

Gambar 1. Posisi peletakan tiga massa coba $120^{\circ}$

Langkah pertama dari metode ini adalah menentukan terlebih dahulu dua bidang penyeimbang, yaitu bidang rotor A dan bidang rotor B disebut bidang A dan bidang B. amplitudo getaran yang diukur pada bidang rotor A dengan massa coba a gram disebut X, sedangkan pada bidang rotor $\mathrm{B}$ amplitudo getaran dengan massa coba $\mathrm{b}$ gram disebut $\mathrm{Y}$.

Prosedur pengukuran getaran ditunjukkan pada Tabel 1. Rotor dapat seimbang bila dipenuhi persamaan matematis sebagai berikut:

$$
\begin{aligned}
& \overrightarrow{\mathrm{X}}=\overrightarrow{\mathrm{X}}_{0}+\overrightarrow{\mathrm{X}}_{a}+\overrightarrow{\mathrm{X}}_{\mathrm{b}}=0 \\
& \overrightarrow{\mathrm{Y}}=\overrightarrow{\mathrm{Y}}_{0}+\overrightarrow{\mathrm{Y}}_{a}+\overrightarrow{\mathrm{Y}}_{\mathrm{b}}=0
\end{aligned}
$$

dimana:

$$
\begin{aligned}
& \overrightarrow{\mathrm{X}}_{0}=\text { amplitudo getaran pada bidang A tanpa massa coba } \\
& \overrightarrow{\mathrm{Y}_{0}}=\text { amplitudo getaran pada bidang B tanpa massa coba } \\
& \overrightarrow{\mathrm{X}}_{a}=\text { amplitudo getaran pada bidang A akibat adanya massa coba pada bidang A } \\
& \overrightarrow{\mathrm{X}_{\mathrm{b}}}=\text { amplitudo getaran pada bidang A akibat adanya massa coba pada bidang B } \\
& \overrightarrow{\mathrm{Y}}_{a}=\text { amplitudo getaran pada bidang B akibat adanya massa coba pada bidang A } \\
& \overrightarrow{\mathrm{Y}_{\mathrm{b}}}=\text { amplitudo getaran pada bidang B akibat adanya massa coba pada bidang B }
\end{aligned}
$$


Karena massa tak seimbang dianggap proporsional terhadap getaran yang ditimbulkan, maka:

$$
\begin{aligned}
& \frac{X_{a}}{a}=\frac{X_{a t}}{a_{t}} \rightarrow \mathrm{X}_{\mathrm{a}}=\frac{a}{a_{t}} \cdot \mathrm{X}_{\mathrm{at}} \\
& \frac{X_{b}}{b}=\frac{X_{b t}}{b_{t}} \rightarrow \mathrm{X}_{\mathrm{b}}=\frac{b}{b_{t}} \cdot \mathrm{X}_{\mathrm{bt}} \\
& \frac{Y_{a}}{a}=\frac{Y_{a t}}{a_{t}} \rightarrow \mathrm{Y}_{\mathrm{a}}=\frac{a}{a_{t}} \cdot \mathrm{Y}_{\mathrm{at}} \\
& \frac{Y_{b}}{b}=\frac{Y_{b t}}{b_{t}} \rightarrow \mathrm{Y}_{\mathrm{b}}=\frac{b}{b_{t}} \cdot \mathrm{Y}_{\mathrm{bt}}
\end{aligned}
$$

Tabel 1. Prosedur pengukuran penyeimbangan dinamik Metode Tiga Massa Coba $120^{\circ}$

\begin{tabular}{clcc}
\hline No & \multicolumn{1}{c}{ Macam Operasi } & Bidang & Hasil Pengukuran \\
\hline 1 & Massa tidak seimbang dipasang pada bidang A dan bidang B, & $\mathrm{A}$ & $\mathrm{X}_{0}$ \\
& rotor diputar & $\mathrm{B}$ & $\mathrm{Y}_{0}$ \\
2 & Massa coba 1 ditambahkan pada bidang A sebesar a gram di & $\mathrm{A}$ & $\mathrm{X}_{\mathrm{a} 1}$ \\
& posisi $0^{\circ}$, rotor diputar & $\mathrm{B}$ & $\mathrm{Y}_{\mathrm{a} 1}$ \\
3 & Massa coba 2 ditambahkan pada bidang A sebesar a gram di & $\mathrm{A}$ & $\mathrm{X}_{\mathrm{a} 2}$ \\
& posisi $120^{\circ}$, massa coba 1 dibuka rotor diputar & $\mathrm{B}$ & $\mathrm{Y}_{\mathrm{a} 2}$ \\
4 & Massa coba 3 ditambahkan pada bidang A sebesar a gram di & $\mathrm{A}$ & $\mathrm{X}_{\mathrm{a} 3}$ \\
& posisi $240^{\circ}$, massa coba 2 dibuka rotor diputar & $\mathrm{B}$ & $\mathrm{Y}_{\mathrm{a} 3}$ \\
5 & Massa coba 3 bidang A dibuka, massa coba 1 ditambahkan & $\mathrm{A}$ & $\mathrm{X}_{\mathrm{b} 1}$ \\
& pada bidang B sebesar b gram di posisi 0 , rotor diputar & $\mathrm{B}$ & $\mathrm{Y}_{\mathrm{b} 1}$ \\
6 & Massa coba 2 ditambahkan pada bidang B sebesar b gram di & $\mathrm{A}$ & $\mathrm{X}_{\mathrm{b} 2}$ \\
& posisi $120^{\circ}$, massa coba 1 dibuka rotor diputar & $\mathrm{B}$ & $\mathrm{Y}_{\mathrm{b} 2}$ \\
7 & Massa coba 3 ditambahkan pada bidang B sebesar b gram di & $\mathrm{A}$ & $\mathrm{X}_{\mathrm{b} 3}$ \\
& posisi $240^{\circ}$, massa coba 2 dibuka rotor diputar & $\mathrm{B}$ & $\mathrm{Y}_{\mathrm{b} 3}$ \\
\hline
\end{tabular}

Persamaan 3, 4, 5, 6 disubstitusikan ke dalam persamaan (1) dan (2) akan diperoleh:

$$
\begin{aligned}
& \overrightarrow{\mathrm{X}_{0}}+\overrightarrow{\mathrm{X}_{\mathrm{at}}} \cdot \frac{a}{a_{t}}+\overrightarrow{\mathrm{X}_{\mathrm{bt}}} \cdot \frac{b}{b_{t}}=0 \\
& \overrightarrow{\mathrm{Y}_{0}}+\overrightarrow{\mathrm{Y}_{\mathrm{at}}} \cdot \frac{a}{a_{t}}+\overrightarrow{\mathrm{Y}_{\mathrm{bt}}} \cdot \frac{b}{b_{t}}=0
\end{aligned}
$$

Pada kedua persamaan tersebut terdapat dua bilangan yang tidak diketahui yaitu $a / a_{t}$ dan $\mathrm{b} / \mathrm{b}_{\mathrm{t}}$, nilainya dapat dicari sebagai berikut:

$$
\frac{a}{a_{t}}=\frac{\left|\begin{array}{cc}
X_{o} & X_{b t} \\
Y_{o} & Y_{b t}
\end{array}\right|}{\left|\begin{array}{cc}
X_{a t} & X_{b t} \\
Y_{a t} & Y_{b t}
\end{array}\right|}
$$

Persamaan (9) dapat diubah bentuknya menjadi

$$
\frac{a}{a_{t}}=\frac{\left|\begin{array}{cc}
1 & \mathrm{X}_{\mathrm{bt}} / \mathrm{X}_{\mathrm{o}} \\
1 & \mathrm{Y}_{\mathrm{bt}} / \mathrm{Y}_{\mathrm{o}}
\end{array}\right|}{\left|\begin{array}{cc}
\mathrm{X}_{\mathrm{at}} / \mathrm{X}_{\mathrm{o}} & \mathrm{X}_{\mathrm{bt}} / \mathrm{X}_{\mathrm{o}} \\
\mathrm{Y}_{\mathrm{at}} / \mathrm{X}_{\mathrm{o}} & \mathrm{Y}_{\mathrm{bt}} / \mathrm{Y}_{\mathrm{o}}
\end{array}\right|}
$$


Dengan cara yang sama juga didapat

$$
\frac{b}{b_{t}}=\frac{\left|\begin{array}{cc}
1 & \mathrm{X}_{\mathrm{at}} / \mathrm{X}_{\mathrm{o}} \\
1 & \mathrm{Y}_{\text {at }} / \mathrm{Y}_{\mathrm{o}}
\end{array}\right|}{\left|\begin{array}{ll}
\mathrm{X}_{\mathrm{at}} / \mathrm{X}_{\mathrm{o}} & \mathrm{X}_{\mathrm{bt}} \mathrm{X}_{\mathrm{o}} \\
\mathrm{Y}_{\mathrm{at}} / \mathrm{X}_{\mathrm{o}} & \mathrm{Y}_{\mathrm{bt}} / \mathrm{Y}_{\mathrm{o}}
\end{array}\right|}
$$

harga-harga $\mathrm{X}_{\mathrm{at}}, \mathrm{X}_{\mathrm{bt}}, \mathrm{Y}_{\mathrm{at}}$ dan $\mathrm{Y}_{\mathrm{bt}}$ diperoleh sebagai berikut:

$X_{\mathrm{at}}=\sqrt{\frac{1}{3}\left(\mathrm{X}_{\mathrm{a} 1}^{2}+\mathrm{X}_{\mathrm{a} 2}^{2}+\mathrm{X}_{\mathrm{a} 3}^{2}\right)-\mathrm{X}_{\mathrm{o}}^{2}}$

$\mathrm{X}_{\mathrm{bt}}=\sqrt{\frac{1}{3}\left(\mathrm{X}_{\mathrm{b} 1}^{2}+\mathrm{X}_{\mathrm{b} 2}{ }^{2}+\mathrm{X}_{\mathrm{b} 3}{ }^{2}\right)-\mathrm{X}_{\mathrm{o}}^{2}}$

$\mathrm{Y}_{\mathrm{at}}=\sqrt{\frac{1}{3}\left(\mathrm{Y}_{\mathrm{a} 1}^{2}+\mathrm{Y}_{\mathrm{a} 2}^{2}+\mathrm{Y}_{\mathrm{a} 3}{ }^{2}\right)-\mathrm{Y}_{\mathrm{o}}^{2}}$

$Y_{b t}=\sqrt{\frac{1}{3}\left(Y_{b 1}{ }^{2}+Y_{b 2}{ }^{2}+Y_{b 3}{ }^{2}\right)-Y_{o}{ }^{2}}$

Indeks 1,2 dan 3 pada $\mathrm{X}_{\mathrm{a} 1}, \mathrm{X}_{\mathrm{a} 2}, \mathrm{Y}_{\mathrm{a} 1}$ dan $\mathrm{Y}_{\mathrm{a} 2}$ dan seterusnya menunjukkan nomor posisi massa coba.

Besar massa penyeimbang di bidang A dan B didapat dengan mengalikan $\frac{a}{a_{t}}$ dan $\frac{b}{b_{t}}$ dengan besar massa coba, dapat dirumuskan sebagai berikut:

$\mathrm{M}_{\mathrm{A}}=\frac{a}{a_{t}} \cdot \mathrm{M}$
$\mathrm{M}_{\mathrm{B}}=\frac{b}{b_{t}} \cdot \mathrm{M}$

dimana:

$$
\begin{aligned}
& M_{A}=\text { besar massa penyeimbang pada bidang } A \\
& M_{B}=\text { besar massa penyeimbang pada bidang } B \\
& m=\text { besar massa coba } \\
& X_{0}=\text { amplitudo getaran pada bidang A tanpa massa coba } \\
& Y_{0}=\text { amplitudo getaran pada bidang } B \text { tanpa massa coba }
\end{aligned}
$$

Posisi massa penyeimbang dapat dicari dengan metode grafis seperti ditunjukkan pada Gambar 2. Untuk mencari posisi massa penyeimbang pada bidang A, $\alpha_{A}$ dapat diikuti langkahlangkah sebagai berikut:

a) Buatlah tiga garis sumbu yang masing-masing bersudut $120^{\circ}$ satu sama lain, kemudian diberi nomor 1,2 dan 3.

b) Dari titik pusat perpotongan sumbu, titik o, buatlah lingkaran dengan jari-jari $\mathrm{X}_{\mathrm{at}}$. Lingkaran tersebut memotong garis sumbu 1,2 dan 3 di titik a,b dan c.

c) Buatlah lingkaran dengan jaro-jari $\mathrm{X}_{\mathrm{a} 1}$, dengan pusat titik $\mathrm{a}$.

d) Buatlah lingkaran dengan jaro-jari $\mathrm{X}_{\mathrm{a} 2}$, dengan pusat titik b.

e) Buatlah lingkaran dengan jaro-jari $\mathrm{X}_{\mathrm{a} 3}$, dengan pusat titik c.

f) Buatlah lingkaran dengan jaro-jari $\mathrm{X}_{0}$, dengan pusat titik 0 .

g) Perpotongan lingkaran dengan jari-jari $\mathrm{X}_{\mathrm{a} 1}, \mathrm{X}_{\mathrm{a} 2}, \mathrm{X}_{\mathrm{a} 3}$ dan $\mathrm{X}_{0}$ menunjukkan posisi massa penyeimbang pada bidang $A$.

Dengan cara yang sama dapat dicari posisi penyeimbang pada bidang $B, \alpha_{B}$. 


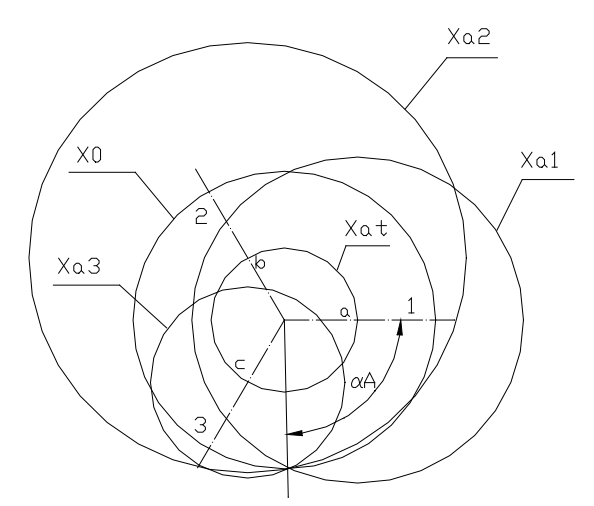

Gambar 2. Analisis grafis metode “Tiga Massa Coba 120”

\section{Oil Whirl/Half Frequency Whirl}

Salah satu bentuk ketidakstabilan yang mungkin terjadi dalam pemakaian bantalan luncur adalah terjadinya oil whirl atau biasa dikenal dengan half - frequency whirl. Fenomena oil whirl merupakan bentuk getaran tereksitasi sendiri yang berupa gerakan pusat sumbu poros yang mengorbit pada sumbu bantalan dengan frekuensi yang mendekati setengah kecepatan rotasi poros. Kecepatan rotasi poros biasa dilambangkan dengan $\omega$ sedangkan kecepatan orbit dilambangkan dengan $\Omega$. Pada umumnya nilai $\Omega$ sebesar setengah dari nilai $\omega$.

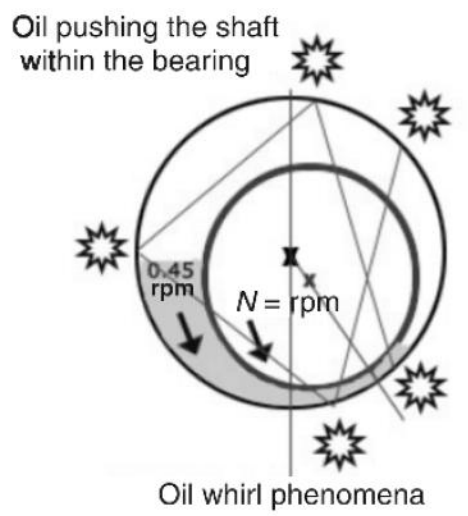

Gambar 3. Kondisi whirling poros pada bantalan

Apabila poros berputar hingga dua kali putaran kritisnya, maka frekuensi oil whirl akan beresonansi denga frekuensi pribadi poros dan berubah menjadi oil whip. Frekuensi oil whip ini tidak bergantung pada naiknya kecepatan putaran poros, akan tetapi tetap berada pada frekuensi pribadi dari sistem poros tersebut.

\section{Karakteristik Sinyal Getaran Pada Model Uji Sistem Poros Rotor}

Pengetahuan tentang karakteristik sinyal getaran sangat penting dalam menganalisis spektrum getaran. Ketidaknormalan pada elemen rotasi akan menimbulkan ciri getaran yang berbeda antara lain:

\section{Unbalance}

Massa tak seimbang merupakan salah satu ketidaknormalan yang sering terjadi dan mudah diidentifikasi pada mesin-mesin rotasi. Unbalance terjadi karena pendistribusian massa yang tidak merata pada suatu komponen dan adanya densitas material yang tidak merata, proses machining, tindakan perawatan, terjadinya lubang "porosity” pada saat proses pengecoran dan lain-lain.

Misalignment adalah suatu kondisi dimana poros tidak berhimpit dengan sumbu putar yang seharusnya. Misalignment berasal dari preload poros yang bengkok ataupun bantalan yang tidak mapan dan sumbu poros pada kopling tidak segaris. Misalignment yang terjadi dapat berupa 
misalignment sudut atau misalignment parallel. Pada umumnya kondisi yang terjadi di lapangan adalah gabungan dari keduanya dengan kombinasi arah horisontal dan vertikal. Gambar 4 menunjukkan bentuk misalignment yang biasa terjadi.
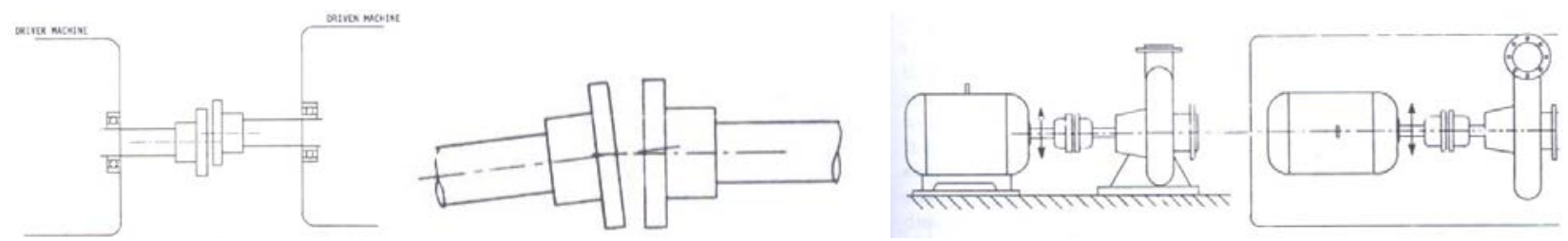

Gambar 4. Berbagai macam misalignment yang mungkin terjadi

Jika kondisi misalignment dibiarkan terus berlangsung tanpa adanya tindakan perbaikan, maka akan terjadi suatu getaran yang relatif besar. Efek yang mungkin terjadi adalah penggunaan bantalan, seal dan kopling dalam waktu yang lebih singkat dibandingkan dengan kondisi normal.

Gejala misalignment muncul pada domain frekuensi yang berbentuk suatu rangkaian sinyal di sekitar frekuensi putaran sistem harmonik.

Karakteristik getaran karena adanya misalignment adalah sebagai berikut:

- Tingkat getaran tinggi pada arah aksial.

- Adanya frekuensi dominan / rangkaian sinyal harmonik pada 2X, 3X rpm dan kelipatannya.

- Sinyal yang muncul pada kedua tumpuan poros menunjukkan beda fasa sebesar $180^{\circ}$.

- Perubahan kecepatan poros tidak begitu berpengaruh terhadap besar amplitudo yang terjadi.

\section{Frekuensi oil whirl dan oil whip}

Karakteristik getaran oil whirl yang membedakan dengan ciri getaran lainnya adalah timbulnya amplitudo yang dominan pada 0,35 - 0,5X kecepatan putaran poros. Analisis orbit dan fasa juga diperlukan untuk mendeteksi fenomena oil whirl. Analisis orbit dan fasa dilakukan dengan memasang dua proximity probes pada satu bidang yang tegak lurus satu dengan lainnya. Terjadinya oil whirl pada umumnya akan membentuk orbit poros yang berbentuk elips dan adanya beda fasa antara dua proximity sebesar $90^{\circ}$. Frekuensi oil whirl akan berubah menjadi oil whip apabila beresonansi dengan putaran kritis poros. Frekuensi oil whip akan selalu berada pada frekuensi yang sama dengan putaran kritis poros.

\section{Analisis Peta Spektrum dan Orbit}

Analisis peta spektrum adalah menggabungkan beberapa spektrum getaran terhadap perubahan putaran, sedangkan analisis orbit adalah menampilkan hasil pengukuran pada domain frekuensi atau domain waktu tertentu yang berbentuk elips yang merupakan posisi lintasan dari poros.

\section{METODE PENELITIAN}

Pengujian sinyal getaran pada sistem poros rotor ganda ini terdiri dari empat tahapan, yaitu pengujian statis untuk memperoleh frekuensi pribadi model, pengujian dinamis sebelum proses penyeimbangan, penerapan metode tiga massa coba $120^{\circ}$ untuk mengurangi gejala unbalance dan pengujian dinamis setelah penyeimbangan.

Dalam penelitian ini akan dilakukan kegiatan eksprimental dengan melakukan uji eksperimental dengan menggunakan model rotor kit, serta mempelajari karakteristik getaran pada model tersebut. Gambar 5 adalah set up peralatan untuk pengambilan data peta spektrum dan Gambar 6 adalah set up peralatan untuk pengambilan data orbit. 


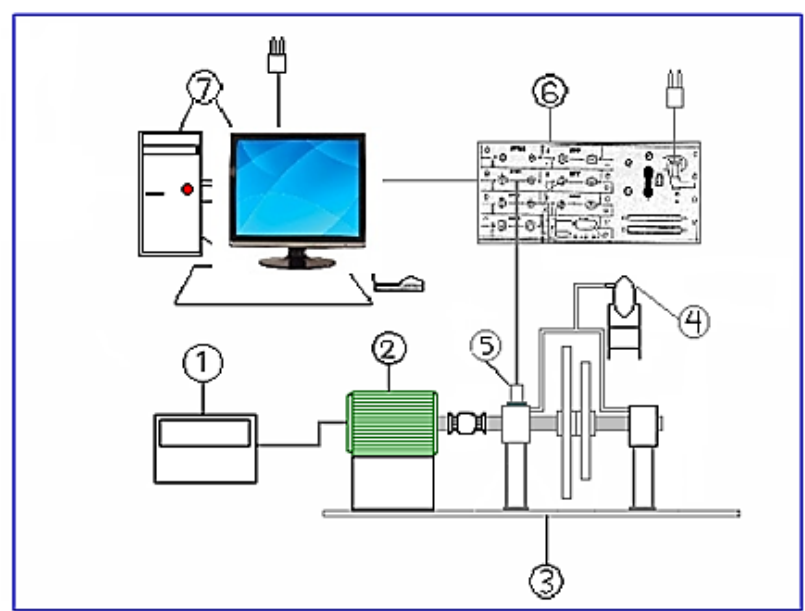

Gambar 5. Set up pengambilan data spektrum getaran

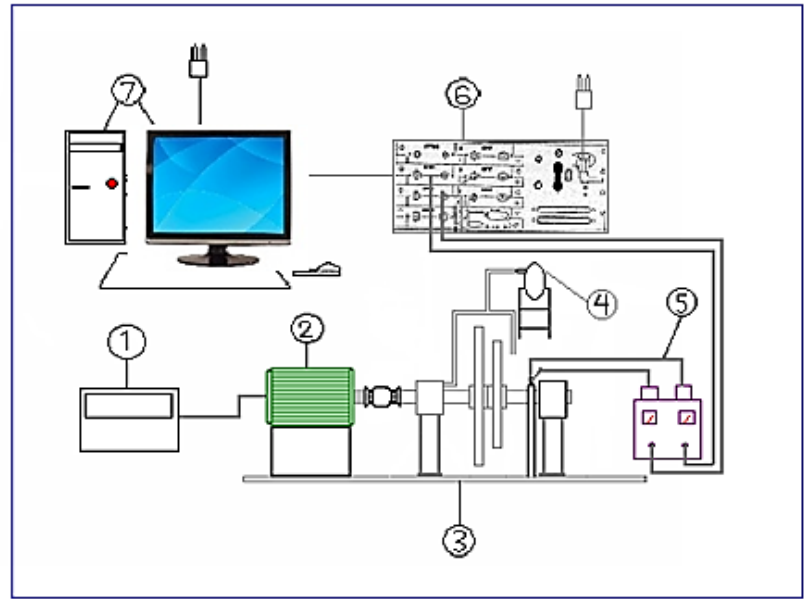

Gambar 6. Set up pengambilan data orbit

\section{HASIL DAN PEMBAHASAN}

Pada kegiatan penelitian ini, telah dilakukan perancangan model rotor kit dengan dua rotor ganda dilanjutkan dengan pembuatan model, mencari frekuensi pribadi struktur, menyelidiki rotor kit ganda dari unbalance, misalignment dan fenomena oil whirl, serta menganalisis karakteristik bantalan luncur, kemudian membuat peta spectrum dan orbit dari struktur rotor kit.

Dalam penelitian ini di buat sebuah model yang digunakan untuk menganalisis pengujian karakteristik getaran pada model rotor ganda menggunakan analisis peta spektrum dan orbit. Perancangan digambar dengan bantuan software engineering CATIA V5 dengan nomor licence AEP-4234100D88B48A5C, yang menghasilkan gambar 3D. Kemudian dibuatkan gambar kerja 2D yang nantinya akan dibawa ke workshop atau bengkel untuk dikerjakan. Di bawah ini adalah Gambar 7 Model Rotor Ganda.

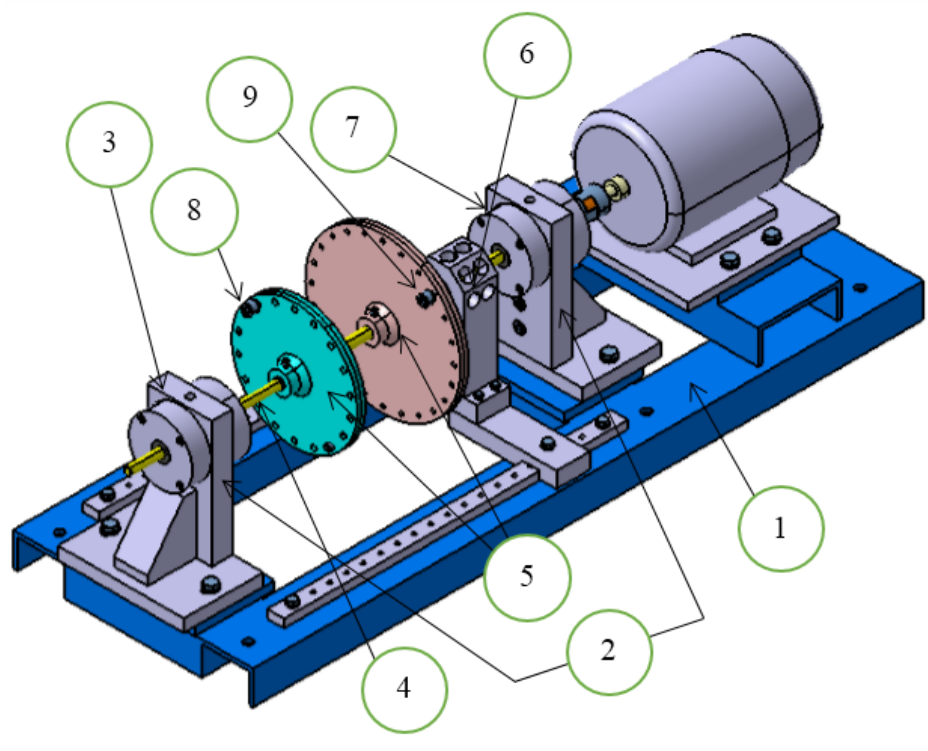

Model Rotor Ganda terdiri dari:

1. Meja Dudukan Model

2. Dudukan poros 2 buah

3. Bantalan Luncur kanan

4. Poros Rotor 1 buah

5. Rotor 2 buah

6. Tempat Sensor

7. Bantalan luncur kiri

8. Penempatan massa penyeimbang A

9. Penempatan massa penyeimbang B

Gambar 7. Model rotor ganda

Pengujian statis dilakukan untuk menentukan frekuensi pribadi sistem dengan cara memberikan impact (berupa pukulan hammer kit) pada beberapa titik di sepanjang bagian sistem poros rotor seperti terlihat pada Gambar 8 di bawah ini. Besar impact tersebut diukur oleh DSA sehingga diperoleh hasil spektrum getaran yang memperlihatkan letak daerah frekuensi pribadi sistem. 


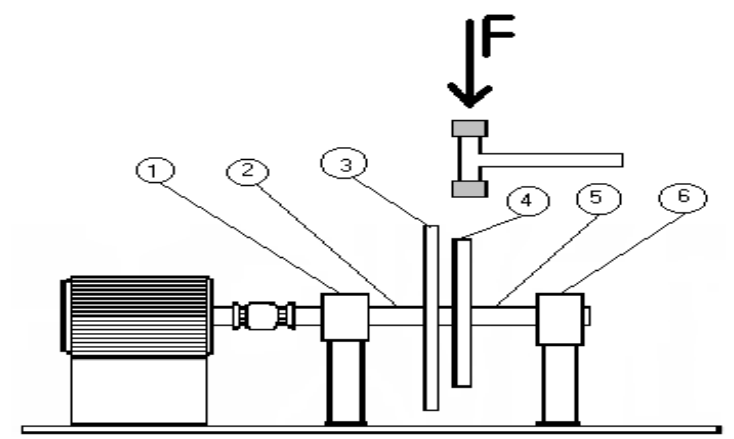

Gambar 8. Posisi titik pengujian

Pengujian ini menghasilkan nilai-nilai frekuensi pribadi sebagai berikut:

Tabel 2. Hasil pengujian frekuensi pribadi

\begin{tabular}{ccccccc}
\hline Titik Pengujian & $\mathbf{1}$ & $\mathbf{2}$ & $\mathbf{3}$ & $\mathbf{4}$ & $\mathbf{5}$ & $\mathbf{6}$ \\
\hline $\mathrm{fn}(\mathrm{Hz})$ & 41,75 & 41,5 & 41,5 & 42 & 41,5 & 41,75 \\
\hline
\end{tabular}

Nilai frekuensi pribadi yang paling banyak muncul adalah $41,5 \mathrm{~Hz}$, dan ini merupakan nilai frekuensi pribadi model uji.

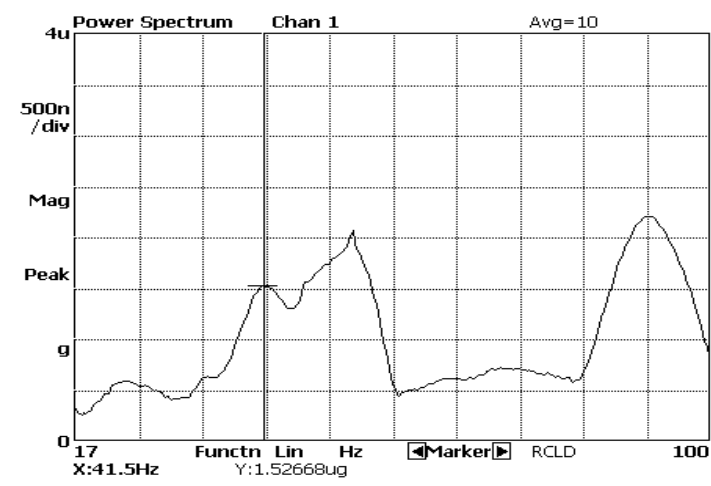

Gambar 9. Frekuensi pribadi struktur

\section{Analisis Data Sebelum Pemasangan Massa Penyeimbang}

Peta spektrum sistem poros rotor ganda sebelum pemasangan massa penyeimbang dapat dilihat pada gambar dibawah ini.

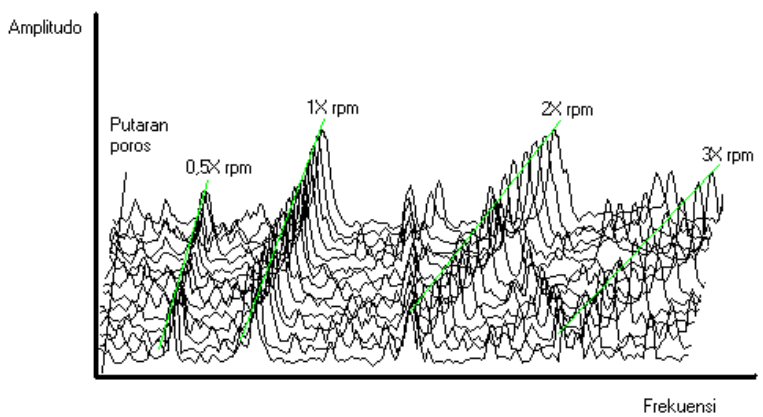

a. Bantalan kiri

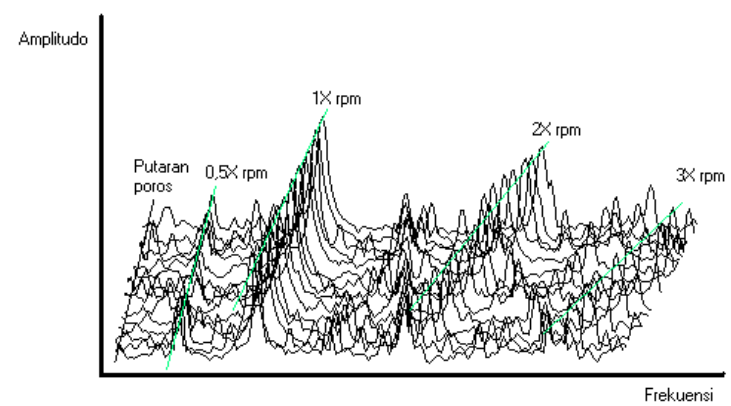

b. Bantalan kanan

Gambar 10. Peta spektrum sistem rotor kit sebelum pemasangan massa penyeimbang untuk putaran 1500 - 2200 rpm dengan kenaikan putaran 50 rpm 
Pada sistem poros rotor terdapat indikasi adanya unbalance, yang ditandai dengan adanya sinyal dominan pada $1 \mathrm{x}$ rpm, level getaran yang tinggi pada arah radial dan kenaikan amplitudo seiring dengan naiknya kecepatan putaran.

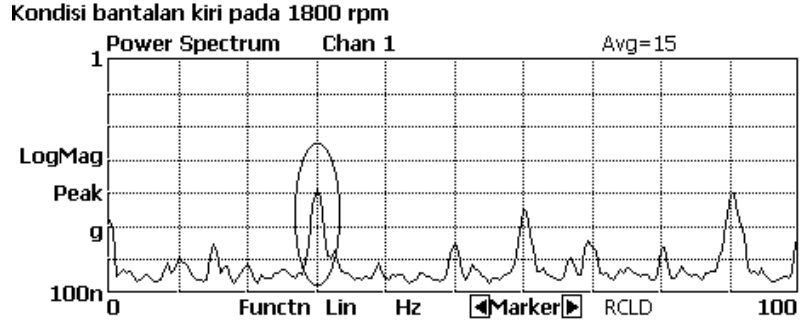

a. Bantalan kiri

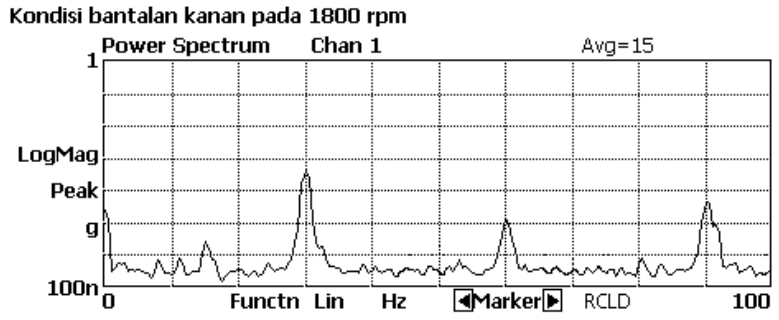

b. Bantalan kanan

Gambar 11. Spektrum getaran menunjukkan kondisi unbalance pada kecepatan putaran $1800 \mathrm{rpm}$

Adanya indikasi misalignment pada sistem poros rotor ganda ini, ditandai dengan adanya sinyal dominan pada $2 \mathrm{X}, 3 \mathrm{X} \mathrm{rpm}$ dan seterusnya. Sinyal ini juga muncul untuk peletakan accelerometer pada arah aksial.

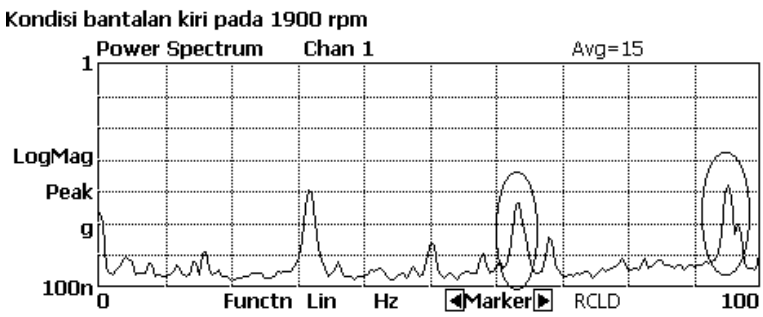

a. Bantalan kiri

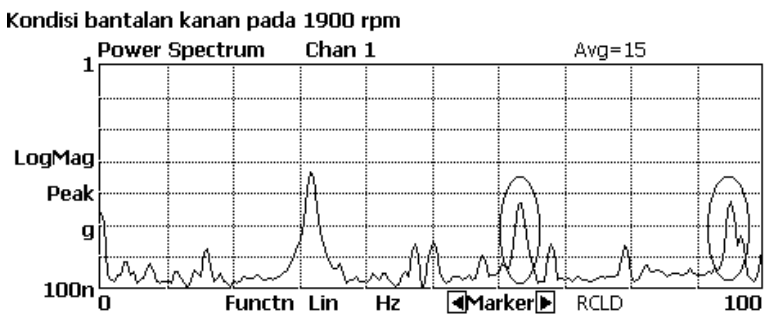

b. Bantalan kanan

Gambar 12. Spektrum getaran dengan kondisi misalignment pada kecepatan putaran $1900 \mathrm{rpm}$

Fenomena oil whirl pada bantalan luncur kiri dan kanan terjadi pada putaran $1500 \mathrm{rpm}$ - 1700 rpm dan putaran $1800 \mathrm{rpm}$ - $2200 \mathrm{rpm}$.

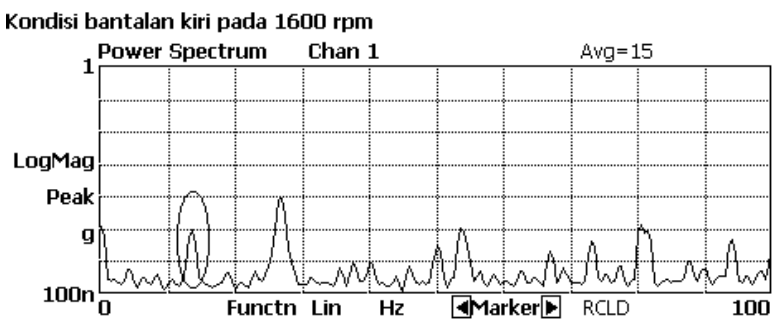

a. Domain frekuensi pada putaran $1600 \mathrm{rpm}$ untuk bantalan kiri

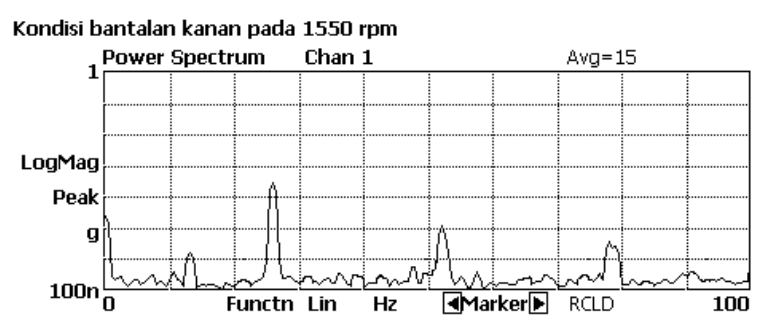

b. Domain frekuensi pada putaran $1500 \mathrm{rpm}$ untuk bantalan kanan

Gambar 13. Spektrum getaran yang menunjukkan kondisi oil whirl

\section{Analisis Data Orbit Sebelum Pemasangan Massa Penyeimbang}

Selain melalui peta spektrum, diperlukan pula analisis orbit untuk mengamati terjadinya fenomena oil whirl. Bentuk orbit poros hasil pengujian diperlihatkan pada gambar di bawah ini. 


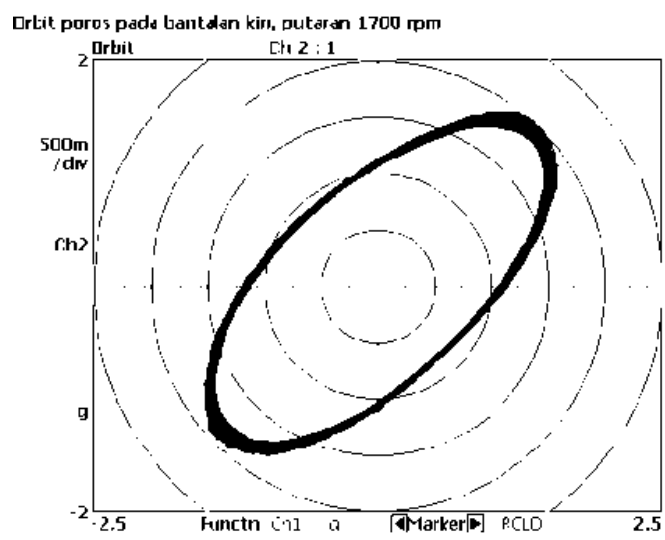

a. Orbit poros bantalan kiri pada putaran $1900 \mathrm{rpm}$

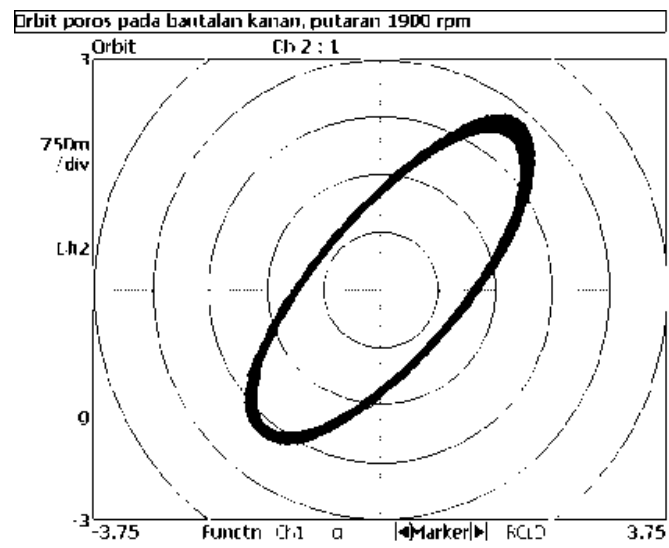

b. Orbit poros bantalan kanan pada $1700 \mathrm{rpm}$

Gambar 14. Orbit poros pada bantalan sebelum penyeimbangan

Orbit poros dengan bentuk elips menunjukkan bahwa poros bergerak relatif terhadap sumbu bantalan. Munculnya sinyal pada rentang frekuensi $0,3-0,5 \mathrm{X}$ rpm dan adanya gerakan relatif sumbu poros mengindikasikan terjadinya fenomena oil whirl pada sistem.

\section{Analisis Data Amplitudo Sebelum Pemasangan Massa Penyeimbang}

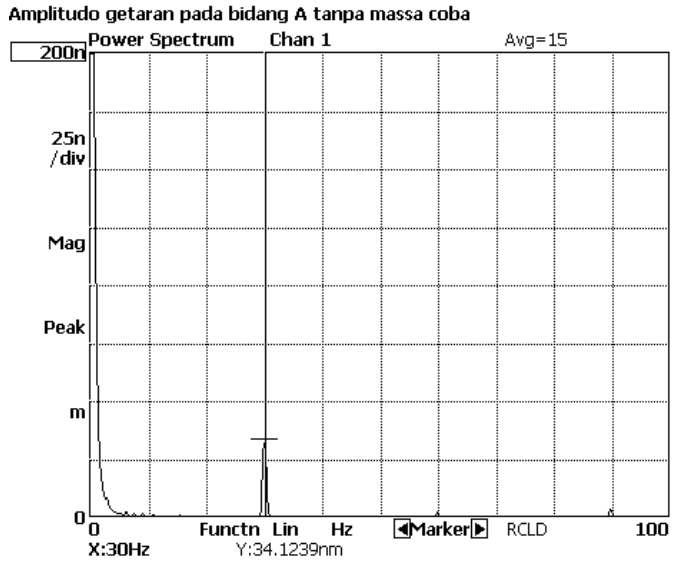

Gambar 15. Hasil pengukuran Metode Tiga Massa Coba $120^{\circ}\left(\mathrm{X}_{0}\right)$

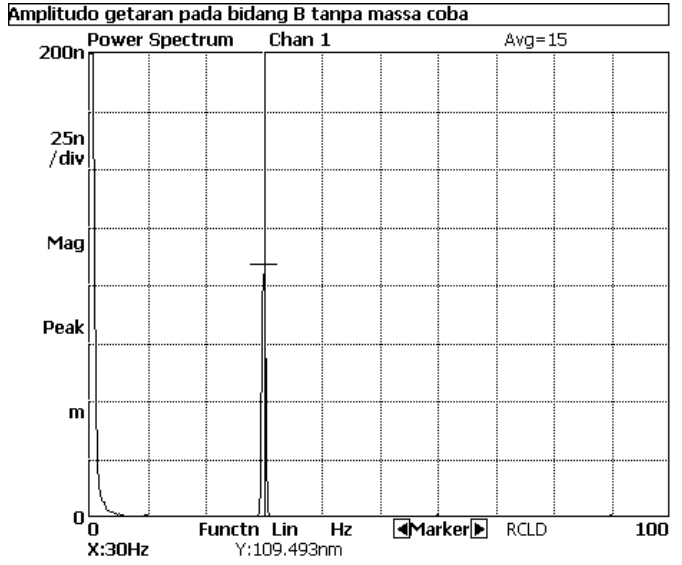

Gambar 16. Hasil pengukuran Metode Tiga Massa Coba $120^{\circ}\left(\mathrm{Y}_{0}\right)$

\section{Proses Penyeimbangan Dinamik Metode Tiga Massa Coba $120^{\circ}$}

Tahapan berikutnya dalam penelitian ini adalah penerapan metode tiga massa coba $120^{\circ}$ untuk mengurangi gejala unbalance dan pengujian dinamis setelah proses penyeimbangan untuk menganalisis peta spektrum getaran dan orbit.

Metode penyeimbangan tiga massa coba $120^{\circ}$ dimulai dengan memasang massa tiga massa coba dengan berat yang sama secara bergantian dengan selisih $120^{\circ}$ satu sama lainnya. Berat massa coba yang digunakan adalah 3,9 gram. Pemilihan ini didasarkan pada kondisi sistem poros rotor di mana massa coba ini bila saling menjumlahkan dengan massa tak seimbang, tidak menyebabkan penambahan getaran yang terlalu besar dan bila saling mengurangi tidak menyebabkan getaran terlalu kecil.

Massa coba dipasang pada kedudukan $0^{\circ}, 120^{\circ}$ dan $240^{\circ}$ secara bergantian pada bidang rotor A dan rotor $\mathrm{B}$. hasil pengujian tersebut dapat dilihat pada Tabel 3. 
Tabel 3. Hasil pengukuran amplitudo getaran pada proses penyeimbangan dinamik Metode Tiga Massa Coba $120^{\circ}$

\begin{tabular}{|c|c|c|c|}
\hline No & Macam Operasi & Bidang & Hasil Pengukuran(nm) \\
\hline \multirow{2}{*}{1} & Massa tidak seimbang dipasang pada bidang A dan bidang & A & $\mathrm{X}_{0}=34,1239$ \\
\hline & B, rotor diputar & B & $Y_{0}=109,4930$ \\
\hline \multirow{2}{*}{2} & Massa coba 1 ditambahkan pada bidang A sebesar 3,9 gram & A & $X_{a 1}=35,8015$ \\
\hline & di posisi $0^{\circ}$, rotor diputar & B & $Y_{a 1}=112,4460$ \\
\hline \multirow{2}{*}{3} & Massa coba 2 ditambahkan pada bidang A sebesar 3,9 gram & A & $X_{\mathrm{a} 2}=44,7159$ \\
\hline & di posisi $120^{\circ}$, massa coba 1 dibuka rotor diputar & $\mathrm{B}$ & $\mathrm{Y}_{\mathrm{a} 2}=135,0210$ \\
\hline \multirow{2}{*}{4} & Massa coba 3 ditambahkan pada bidang A sebesar 3,9 gram & A & $X_{a 3}=24,4743$ \\
\hline & di posisi $240^{\circ}$, massa coba 2 dibuka rotor diputar & B & $\mathrm{Y}_{\mathrm{a} 3}=90,1207$ \\
\hline \multirow{3}{*}{5} & Massa coba 3 bidang A dibuka, massa coba 1 ditambahkan & A & $X_{b 1}=35,5812$ \\
\hline & pada bidang B sebesar 3,9 gram di posisi $0^{\circ}$, rotor diputar & B & $Y_{\mathrm{b} 1}=114,0870$ \\
\hline & Massa coba 2 ditambahkan pada bidang B sebesar 3,9 gram & A & $X_{b 2}=43,3993$ \\
\hline 6 & di posisi $120^{\circ}$, massa coba 1 dibuka rotor diputar & B & $Y_{\mathrm{b} 2}=133,8970$ \\
\hline \multirow{2}{*}{7} & Massa coba 3 ditambahkan pada bidang B sebesar 3,9 gram & A & $X_{b 3}=27,1952$ \\
\hline & di posisi $240^{\circ}$, massa coba 2 dibuka rotor diputar & B & $Y_{\mathrm{b} 3}=97,4333$ \\
\hline
\end{tabular}

\section{Nilai penyeimbangan yang dihasilkan} berikut:

Dengan menggunakan persamaan-persamaan diatas, didapatkan hasil perhitungan sebagai

$$
\begin{array}{ll}
\mathrm{X}_{\mathrm{at}}=11,3568 \mathrm{~nm} \quad \mathrm{X}_{\mathrm{bt}}=11,4859 \mathrm{~nm} \quad \mathrm{Y}_{\mathrm{at}}=31,7824 \mathrm{~nm} \quad \mathrm{Y}_{\mathrm{bt}}=38,6063 \mathrm{~nm} \\
\frac{a}{a_{t}}=0,8151 \quad \frac{b}{b_{t}}=2,165
\end{array}
$$

Dengan demikian besar massa penyeimbangan pada bidang A dan B adalah:

$$
\begin{aligned}
& \mathrm{M}_{\mathrm{A}}=0,8151 \times 3,9 \text { gram }=3,1789 \approx 3,2 \text { gram } \\
& \mathrm{M}_{\mathrm{B}}=2,165 \times 3,9 \text { gram }=8,4435 \approx 8,4 \text { gram }
\end{aligned}
$$

Posisi $\mathrm{M}_{\mathrm{A}}$ dan $\mathrm{M}_{\mathrm{B}}$ didapat dengan melakukan analisis grafis. Dari analisis grafis pada Gambar 24, didapat hasil sebagai berikut:

$$
\alpha_{\mathrm{A}}=88^{\circ} \text { dan } \alpha_{\mathrm{B}}=89^{\circ}
$$

Massa $\mathrm{M}_{\mathrm{A}}$ sebesar 3,1789 gram diletakkan pada bidang A dengan posisi $\alpha_{\mathrm{A}}=272^{\circ}$ dan massa $M_{B}$ sebesar 8,4435 gram diletakkan pada bidang $B$ dengan posisi $\alpha_{B}=271^{\circ}$, kemudian rotor diputar dan didapat:

$$
\mathrm{X}_{\mathrm{S}}=14,8279 \mathrm{~nm} \text { dan } \mathrm{Y}_{\mathrm{S}}=59,6817 \mathrm{~nm}
$$

Dengan demikian besar prestasi penyeimbangan diperoleh:

$$
\begin{aligned}
& P_{X}=\frac{34,1239-14,8279}{34,1239} \cdot 100 \%=56,55 \% ; \\
& P_{Y}=\frac{109,4930-59,6817}{109,4930} \cdot 100 \%=45,5 \%
\end{aligned}
$$




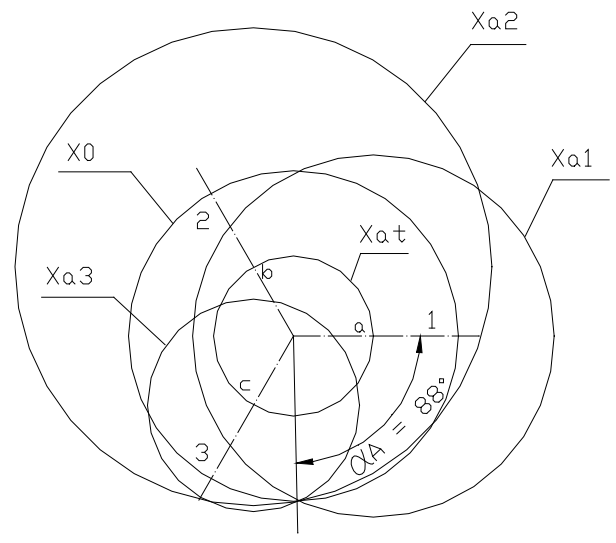

Bidang A

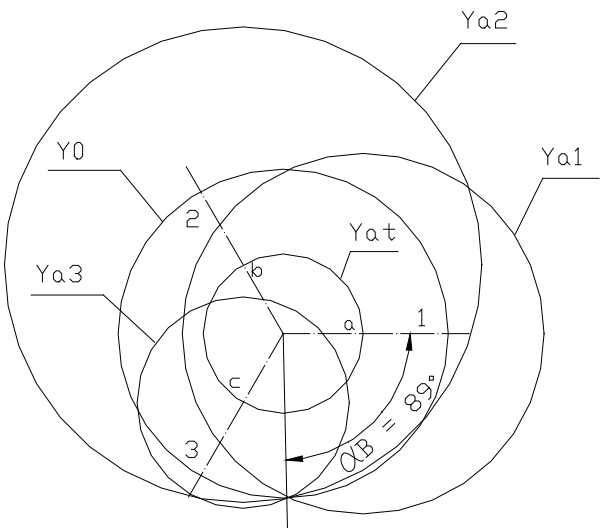

Bidang B

Gambar 17. Analisis grafis penyeimbangan Tiga Massa Coba $120^{\circ}$ untuk penentuan posisi

\section{Analisis Data Setelah Pemasangan Massa Penyeimbang}

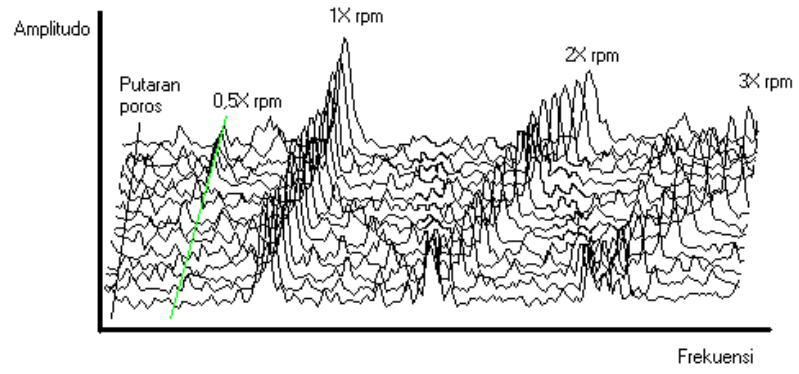

a. Bantalan kiri

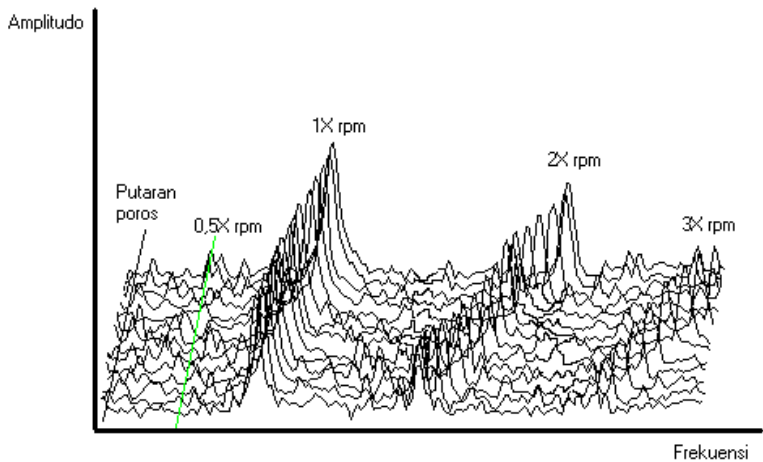

b. Bantalan kanan

Gambar 18. Peta spektrum sistem rotor kit setelah pemasangan massa penyeimbang untuk putaran 1500 - 2200 rpm dengan kenaikan putaran 50 rpm

Pemasangan massa penyeimbang dapat dilihat pada Gambar 7, setelah dipasang massa penyeimbang, amplitudo unbalance berkurang rata-rata 55\%. Penyeimbangan sistem poros rotor ini juga berpengaruh pada berkurangnya fenomena oil whirl yang terjadi. Ini menunjukkan bahwa adanya gaya sentrifugal yang ditimbulkan oleh rotor unbalance menyebabkan munculnya fenomena oil whirl pada bantalan luncur.

Untuk bantalan kanan, karakteristik bantalan luncur muncul pada putaran 2150 rpm. Sedangkan untuk bantalan kiri fenomena oil whirl muncul pada putaran 2100 rpm.

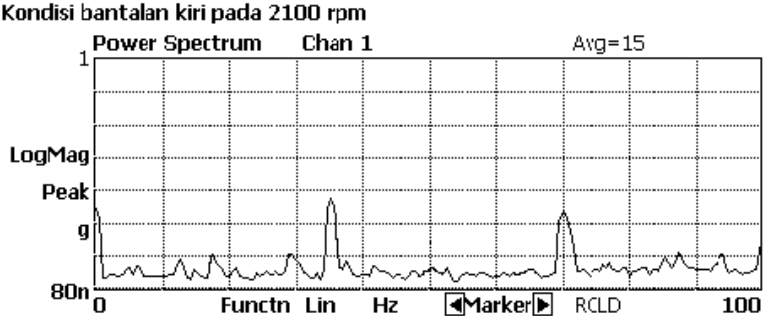

a. Domain frekuensi bantalan kiri $2100 \mathrm{rpm}$

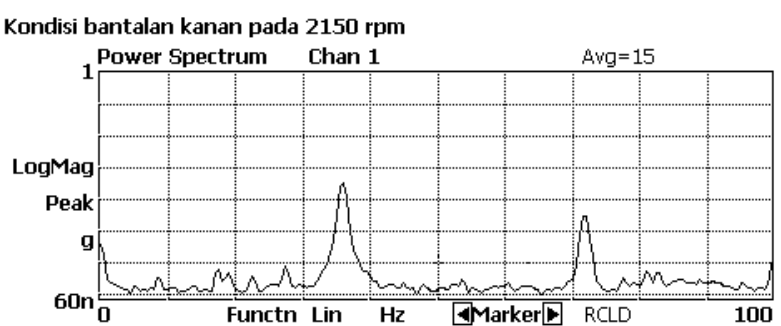

b. Domain frekuensi bantalan kanan 2150 rpm

Gambar 19. Spektrum getaran yang menunjukkan kondisi oil whirl setelah penyeimbangan 


\section{Analisis Data Orbit Setelah Pemasangan Massa Penyeimbang}

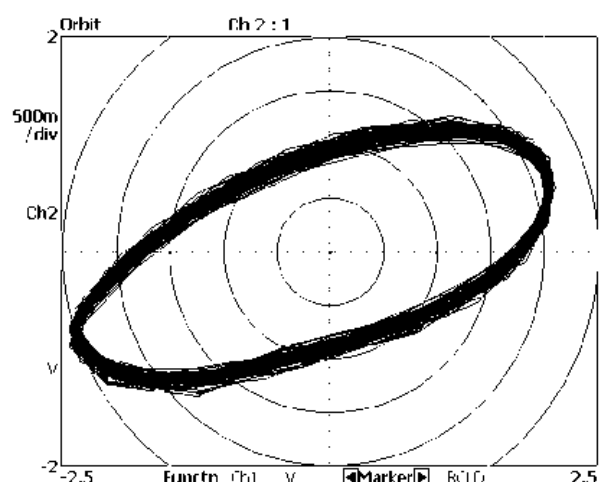

a. Orbit poros bantalan kiri putaran $2100 \mathrm{rpm}$

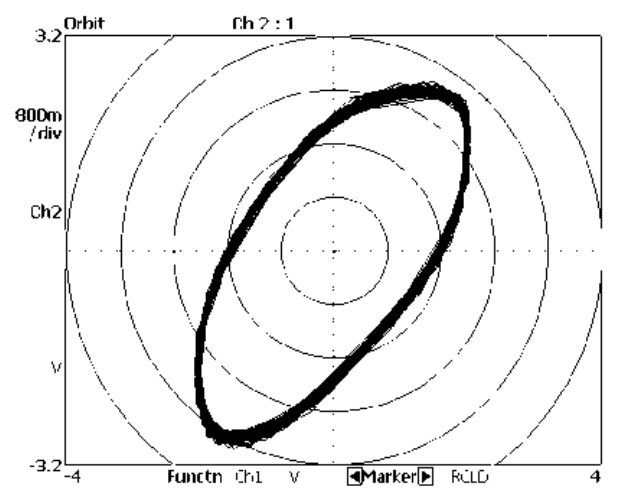

b. Orbit poros bantalan kanan putaran $2100 \mathrm{rpm}$

Gambar 20. Orbit poros pada bantalan setelah penyeimbangan

Orbit poros yang berbentuk elips serta munculnya sinyal pada 0,5 rpm menunjukkan bahwa fenomena oil whirl terjadi pada bantalan luncur untuk putaran $2100 \mathrm{rpm}$. Fenomena oil whirl tidak tampak begitu jelas pada peta spektrum sehingga memerlukan ketelitian dalam mengamati sinyalsinyal yang ada.

\section{Analisis Data Amplitudo Setelah Pemasangan Massa Penyeimbang}

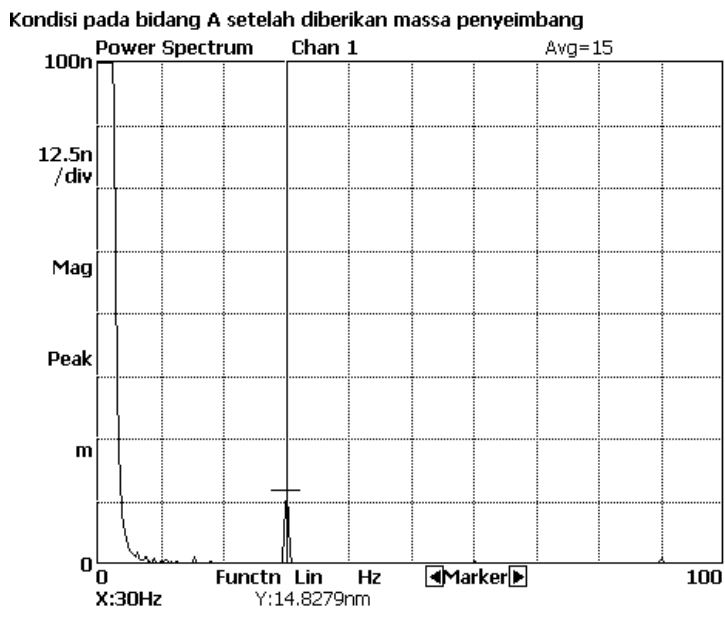

Gambar 21. Hasil pengukuran Metode Tiga Massa Coba $120^{\circ}\left(\mathrm{X}_{\mathrm{S}}\right)$

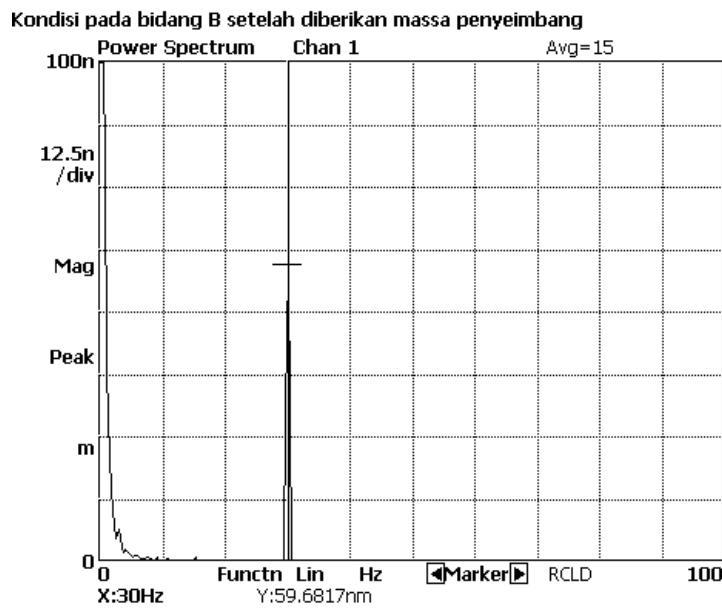

Gambar 22. Hasil pengukuran Metode Tiga Massa Coba $120^{\circ}\left(\mathrm{Y}_{\mathrm{S}}\right)$

\section{SIMPULAN}

Pengujian sistem poros rotor ganda ini merupakan suatu langkah awal dalam mempelajari karakteristik sinyal getaran yang dihasilkan sistem, khususnya mengenai masalah unbalance pada elemen rotasi dan fenomena oil whirl pada bantalan luncur. Hasil pengujian ini menghasilkan beberapa kesimpulan yang dapat diterapkan untuk pengujian selanjutnya. Nilai frekuensi pribadi yang paling banyak muncul adalah $41,5 \mathrm{~Hz}$, dan ini merupakan nilai frekuensi pribadi model uji. Pada sistem rotor kit terdapat adanya kondisi unbalance yang ditandai dengan sinyal dominan pada 1X rpm. Pada sistem rotor kit terdapat adanya kondisi misalignment yang ditandai dengan sinyal dominan pada $2 \mathrm{X}$ dan $3 \mathrm{X}$ rpm. Karakteristik dari bantalan luncur sebelum rotor sistem diseimbangkan adalah munculnya fenomena oil whirl. Kondisi ini diindikasikan dengan munculnya sinyal-sinyal pada $0,5 \mathrm{X}$ rpm dan poros yang mengalami gerakan relatif terhadap sumbunya, yang ditandai dengan adanya orbit berbentuk elips. Fenomena oil whirl pada bantalan luncur kiri dan kanan terjadi pada putaran 1500 rpm - 1700 rpm dan putaran $1800 \mathrm{rpm}$ - $2200 \mathrm{rpm}$. Orbit poros 
dengan bentuk elips menunjukkan bahwa poros bergerak relatif terhadap sumbu bantalan. Munculnya sinyal pada rentang frekuensi 0,3 - 0,5X rpm dan adanya gerakan relatif sumbu poros mengindikasikan terjadinya fenomena oil whirl pada sistem. Setelah pemasangan massa penyeimbang, amplitudo unbalance berkurang rata-rata 55\%. Adanya gaya lain yang bekerja pada sistem rotor kit (gaya sentrifugal akibat unbalance) merupakan salah satu faktor penyebab terjadinya fenomena oil whirl disamping faktor viskositas dan kecepatan aliran pelumas. Hal ini dibuktikan dengan berkurangnya fenomena oil whirl setelah proses penyeimbangan dilakukan. Setelah penyeimbangan orbit poros yang berbentuk elips serta munculnya sinyal pada 0,5 rpm menunjukkan bahwa fenomena oil whirl terjadi pada bantalan luncur untuk putaran $2100 \mathrm{rpm}$.

\section{DAFTAR PUSTAKA}

[1] Bagiasna Komang, Diktat Kuliah Getaran Permesinan Tingkat Lanjut, ITB, Bandung, 1999.

[2] Bagiasna Komang, Bahan Kuliah Kursus Singkat Getaran Permesinan Tingkat Lanjut, Lab. Dinamika PPAU-IR, ITB, Bandung, 1997.

[3] Cameron Allistair, Basic Lubrication Theory, Ellis Horwood Limited, England, 1981.

[4] Eddy Noor. Analisis Getaran pada Bantalan Luncur yang Diakibatkan oleh Pengaruh Kekentalan Pelumasan. Proc. Seminar Nasional Aplikasi Sains dan Teknologi (SNAST 2014). ISSN: 1979-911X. November 2014.

[5] Eddy Noor. Analisis Spektrum Getaran Untuk Mengindentifikasi Sinyal Misalignment pada Belt dan Unbalance pada Model Uji Sistem Transmisi Roda Gigi Differensial, Proc. Seminar Nasional Teknologi Industri (SNTI) 2008. ISBN: 978-979-18265-0-1, Juli, 2008.

[6] Eddy Noor, Analisis Fenomena Oil Whirl pada Sistem Poros Rotor Ganda. Proc. Seminar Nasional Mesin dan Industri (SNMI3) 2007, ISBN : 978-979-95752-7-2, September, 2007.

[7] Eddy Noor, Eksperimental Getaran pada Model Transmisi Roda Gigi dalam Jenis Lurus. J. MESIN, Vol. 8, No. 3, Oktober, 2006.

[8] Eddy Noor, Eksperimental Getaran pada Model Transmisi Roda Gigi dalam Jenis Lurus. J. MESIN, Vol. 8, No. 3, Oktober, 2006.

[9] Eddy Noor, Analisa Spektrum Getaran untuk Mengidentifikasi Sinyal Kontak Gigi dalam Sistem Transmisi Roda Gigi Diferensial dengan Memanfaatkan Creative Soundblaster Audigy LS 5.1 dan Matlab 6.5, J. MESIN, Vol. 8, No. 2, Mei, 2006.

[10] Eddy Noor, Analisis Getaran untuk Mengetahui Karakteristik Komponen-Komponen Suatu Mesin Rotasi. Proc. Seminar Nasional Mesin dan Industri (SNMI) 2005, ISBN : 979-95752-57, September, 2005.

[11] Eddy Noor, Analisis Getaran untuk Mengetahui Karakteristik Komponen - Komponen Suatu Mesin Rotasi. Proc. Seminar Nasional Mesin dan Industri (SNMI) 2005, ISBN : 979-95752-57, September, 2005.

[12] Fuller Dudley D, Theory and Practice of Lubrication for Engineer, John Wiley and Sons, 1984.

[13] Goldman Steve, Vibration Spectrum Analysis, Industrial Press, Inc., ISBN 10: 0831130881/ISBN 13: 9780831130886, 2017.

[14] Holowenko A.R., Dinamika permesinan, Terjemahan Cendy Prapto, Jakarta, Erlangga, 2001.

[15] Nn, 'Effective Machinery Measurements using Dinamic Signal Analyzers', Application Note 243-1 Hewlett Packard.

[16] Spotts Merhyle F., et all, in Design of Machine Elements $8^{\text {th }}$ Edition, Pearson, 2003.

[17] Vierck Robert K, Vibration Analysis, in International Text Book Company, New York, 1967.

[18] Wowk Victor, Measurement and Analysis, in Machinery Vibration, McGraw-Hill Education, ISBN 10: 0070719365/ISBN 13: 9780070719361, 2017.

[19] Wowk Victor, Alignment, in Machinery Vibration, McGraw-Hill Professional, ISBN 10: 007071939X ISBN 13: 9780070719392, 2000. 